Nuntius Antiquus, Belo Horizonte, v. 12, n. 2, p. 225-261, 2016

\title{
Uma comparação entre a interpretação de Kretzmann sobre a correção dos nomes no Crátilo de Platão e as teorias do significado de David Lewis
}

\author{
A comparison between Kretzmann interpretation \\ of the correctness of names in Plato's Cratylus \\ and the theories of the meaning of David Lewis
}

\author{
Ralph Leal Heck \\ Universidade Federal do Ceará \\ Fortaleza, Ceará / Brasil \\ imagomundi@hotmail.com
}

Resumo: O presente artigo tem o objetivo de propor a continuidade dos temas tratados no diálogo Crátilo de Platão pelo filósofo analítico David Lewis, a partir da associação entre suas teorias do significado e as teorias da linguagem contidas na obra platônica, em especial, aquelas defendidas pelo personagem Sócrates, deduzidas assim, pela leitura de Norman Kretzmann e revisadas segundo algumas críticas direcionadas ao intérprete, de modo a provar a semelhança de escopo e dimensão linguística entre a teoria filosófica da linguagem em Platão e a teoria filosófica da linguagem em Lewis. Para executar esta tarefa, iniciarei com a apresentação das principais teses sobre a correção dos nomes contidas no Crátilo, na forma de dois desdobramentos: o critério de nomeação das coisas e a pergunta pela origem dos nomes. Em seguida, farei um panorama das fontes que formam o arcabouço conceitual no qual Platão obtém as teses discutidas no interior da obra, passando pelos sucessores do pensamento platônico no que compete às concepções convencionalista e naturalista da linguagem, culminando na Filosofia analítica da linguagem. Após isto, será feita a exposição da interpretação de Kretzmann sobre as teorias da linguagem contidas no Crátilo, na forma de suas certification question e demonstration question, 
seguida da apresentação das teorias do significado (semântica e fundacional) de Lewis. E, por fim, as teorias de ambos os filósofos serão postas lado a lado, acompanhadas da revisão da concepção de convencionalismo com base nas críticas de Rachel Barney e findando com alguns resultados da comparação entre as teorias em jogo.

Palavras-chave: correção dos nomes; teorias do significado; Platão; David Lewis; Norman Kretzmann.

Abstract: This article aims to propose the continuation of the themes appeared in Plato's dialogue Cratylus by the analytical philosopher David Lewis, through the association of his theories of meaning to the theories of language contained in Plato's work, in particular those advocated by Socrates, so obtained, by Norman Kretzmann's readings and revised according to some criticism directed to the interpreter, in order to prove the similarity of scope and linguistic dimension between the philosophical theory of language in Plato and the philosophical theory of language in Lewis. To perform such task, I will begin with the presentation of the main theses on the correctness of names contained in the Cratylus, in the form of two developments, the criterion for naming things and the question about the origin of names. Then I shall make an overview of the conceptual framework's sources in which Plato takes the theories discussed inside his work, through the successors of Platonic thought as it is for the conventionalist and naturalist conceptions of language, culminating in analytical philosophy of language. After this, I present Kretzmann interpretation on the theories of language contained in Cratylus in the form of their certification question and demonstration question, followed by the presentation of Lewis' theories of meaning (semantical and foundational). And finally, the theories of both philosophers will be placed side by side, followed by the critical review of conventionalism based on Rachel Barney writings, ending with some results from the comparison between the theories at stake.

Keywords: correctness of names; theories of meaning; Plato; David Lewis; Norman Kretzmann.

Recebido em 17 de novembro de 2015. Aprovado em 22 de março de 2016. 


\section{Platão, $O$ Crátilo e a Filosofia da linguagem}

O diálogo platônico Crátilo levanta, dentre várias questões, a pergunta "sobre a correção dos nomes" (perì onomáton orthótêtos) na forma de uma investigação da personagem de Sócrates sobre as teses das personagens de Crátilo e Hermógenes. Para Crátilo, discípulo de Heráclito, os nomes expressam a natureza das coisas. Para Hermógenes, os nomes são fruto de convenções e consentimentos individuais ou grupais, semelhantemente à tese defendida por Protágoras. Como aponta Ademollo (2011, p. 4), há duas instâncias investigativas levadas a cabo por Sócrates sobre a correção dos nomes. A primeira instância diz respeito ao critério fundamental de nomeação das coisas, ou seja: o que justifica a relação entre nome e referente. A segunda instância diz respeito à pergunta pela origem dos nomes. ${ }^{1}$

A primeira instância se encerra em uma aparente aporia, já que Sócrates aponta a inconsistência no valor etimológico dos nomes, rejeitando parcialmente ${ }^{2}$ tese de origem poética, como a de Hermógenes, e a tese originária dos filósofos da Phýsis, que é o caso de Crátilo. Entretanto, como aponta Sedley (2003), a escolha da forma dialógica e dialética da obra platônica representa a própria expressão da Filosofia de Platão, manifesta em seu estilo literário e no comportamento do personagem Sócrates, que, no interior do Crátilo (390c), atesta o modo dialético como o mais adequado ao emprego dos nomes. Isto nos permite afirmar que a primeira instância (a pergunta pela correção no emprego dos nomes) não se resolve na escolha de um fundamento nos termos dos antecessores de Platão, nas vozes e argumentos de Hermógenes e Crátilo, mas, outrossim, numa dimensão dialógica e pragmática de emprego dos nomes (MONTENEGRO, 2007, p. 367-377). São exemplos disto a fala de Sócrates, empregando o próprio método dialético, ao mostrar que deve haver uma técnica no emprego dos nomes (391d-394b), somada à possibilidade dos nomes falsos (430d-e), e sua concordância com o caráter convencional na escolha dos nomes $(434 \mathrm{e}, 435 \mathrm{~b})$ e do papel do dialético nesta escolha.

\footnotetext{
${ }^{1}$ Nomes entendidos aqui como nomes corretos.

${ }^{2}$ A rejeição é parcial, pois nas investigações etimológicas (consagradamente fantasiosas), Sócrates conclui significados que ora favorecem os poetas (410c), ora favorecem os filósofos da phýsis, em especial, Heráclito (411c-412b).
} 
A segunda instância envolve a pergunta pelas condições de construção de um nome, ou, em termos contemporâneos, uma pergunta pelo critério de construção de uma semântica. Para o naturalismo de Crátilo, somente a correção na imposição dos nomes não é condição suficiente para um nome correto. Deve haver um critério, de fato, uma arte (428d-429b) no ato de criar um nome que designe o ser (ousía) da coisa nomeada. Ao passo que, para a tese convencionalista de Hermógenes, apenas a atribuição (imposição) do nome é condição suficiente (384d-e). Esta investigação chega ao nomoteta (388c-389a), o artífice dos nomes. Uma vez que as palavras retratam as coisas, e elas são usadas para ensinar, deve haver uma arte para a sua construção, portanto, uma virtude correspondente. Assim, a semântica platônica, de acordo com Sedley (2003, p. 81-86), é construída por meio da função de designação, a saber, imitar por meio de sons o ser da coisa designada, indicando sua essência ou separando-a das outras coisas, independentemente das sílabas que usemos, contanto que as palavras preservem a mesma força expressiva (no caso dos sinônimos): em uma situação mínima, a função é designar o estado (momentâneo) de algo, em uma situação maximal, a função é designar a própria essência da coisa.

A compreensão do que está em jogo nestas duas questões demanda a explicação do pano de fundo filosófico instanciado pelos argumentos convencionalista de Hermógenes e naturalista de Crátilo. Das influências convencionalistas, temos a visão de Protágoras, especialmente levantada em (385e-386a), que nega a independência das coisas em relação aos sujeitos, onde cada opinião é verdadeira para cada sujeito. Sejam elas propriedades perceptuais ou não, elas são relativas à percepção e ao julgamento de cada um. Desta visão, Hermógenes aproxima-se pelas noções de convenção, pela relação entre indivíduos e comunidades, pela mudança arbitrária (de nomes, no caso) e pela validade temporária (dos nomes). Ademais, para o personagem do diálogo (386a), esta tese diz respeito a um relativismo linguístico, ao passo que, para Protágoras, trata-se de um relativismo ontológico, ou seja, de como as coisas são. ${ }^{3}$ Há ainda outros que compõem este cenário do relativismo (433e), como Empédocles e Tucídides (ADEMOLLO, 2011, p. 89-90). O primeiro afirma que é possível que uma expressão possa ter seu referente trocado

${ }^{3} \mathrm{O}$ que significa, em último caso, que convencionalismo não implica relativismo (ADEMOLLO, 2011. p. 80). 
por razões convencionais, já o segundo defende que os nomes podem expressar, ora um determinado conceito, valor, propriedade, ora outro diverso, ou mesmo seu inverso, ao sabor da moral, costumes e léxico vigentes (BARNEY, 2001, p. 11-13; p. 36-41). Mas, dentre as influências de Hermógenes, o pensador originário da tese convencionalista ( $d a$ linguagem) e que mais se aproxima de sua tese é Demócrito, que afirma a possibilidade de múltiplos nomes para uma mesma coisa. São influências sobre Crátilo (ADEMOLLO, 2011, p. 215-222) os teóricos do fluxo e do princípio penetrante (penetrating principle), ${ }^{4}$ tais como Heráclito e Anaxágoras, e os filósofos atomistas, como Leucipo e Demócrito, que são evocados na investigação etimológica da personagem Sócrates (412c-413d), acerca dos nomes que "foram estabelecidos como se todas as coisas estivessem em movimento, correndo e sendo geradas". 5

Os temas tratados no Crátilo marcam de maneira profunda o pensamento filosófico. Da Antiguidade à modernidade, a tese instanciada por Hermógenes foi discutida por Diodoro Cronos ${ }^{6}$ e, também, reformulada por Aristóteles em De interpretatione (ANGIONI, 2006). No período medieval, Santo Agostinho na obra de juventude $D e$ Dialectica, influenciado também pelas Categorias de Aristóteles, fornece um refinamento das noções de significado da palavra e significado do falante. Parafraseando Nobile (2011, p. 104), Tomás de Aquino vai buscar em Aristóteles a concepção convencionalista de linguagem e a inclui na Summa Theologica, que fundará a doutrina oficial do aristotelismo cristão. Ainda influente, a tese reaparece na De vulgari eloquentia de Dante, na Logique de Arnauld e Nicole da escola de Port-Royal, e também no Discours physique de la parole de Gerard de Cordemoy e no Essay concerning human understanding de John Locke.

Já a tese instanciada por Crátilo é reformulada por Epicuro em sua Epistula ad Herodotum, ressurgindo de diferentes formas nos Estoicos, que influenciados pela obra de Platão, herdaram três principais teses (LONG, 2005, p. 36-37): o recurso à etimologia, em especial o nome dos deuses; o

\footnotetext{
${ }^{4}$ Ademollo, 2011, p. 218-225.

${ }^{5}$ Platão, Crátilo (411c. 5) - trad. Celso O. Vieira.

${ }^{6}$ Embora Diodoro Cronos aceite que a convenção desempenha um papel no emprego dos nomes, o significado para ele parte de um princípio mais fundamental: a intenção do falante, a partir da qual uma expressão ambígua seria resultado da incapacidade do falante em expressar sua intenção claramente (SEDLEY, 1977, p. 102-103).
} 
conceito de sons elementares que significam as coisas, suas propriedades e movimento a partir da mimese; a associação entre fonética e semântica. Subsistindo no medievo, através da tradição judaica, "começando com o fundador anônimo da Kabbalah, a Sepher Yezira (O Livro da Formação, por volta do século VI) até o clássico de Abraham Abulafia Or ha-Śekel (A luz do Intelecto, cap. VIII, p. 5, cerca de 1280)". ${ }^{7}$ O naturalismo linguístico reaparece na idade moderna com a redescoberta de Epicuro na obra de Pierre Gassendi Animadversiones, tomando sua forma completa nos trabalhos de Leibniz: Brevis Designatio... ex indicio linguarum e Essay. Vindo ainda a ocupar um importante papel na Scienza Nuova de Giambattista Vico. Permanecendo presente na modernidade nas obras Grammaire de Étienne Bonnot de Condillac, Grammaire philosophique de Dieudonne Thiebault e Verschiedenheit des menschlichen Sprachbaues de Wilhelm von Humboldt. Este último, ao lado de Bolzano com a obra Wissenschaftslehre e Frege com a obra Grundgesetze der Arithmetik, compõe o cenário das teses que formam a discussão filosófica nos fins do século XIX acerca de uma teoria da linguagem com vistas a uma teoria universal, de estrutura formal e abstrata comum a todas as linguagens (FILHO, 1995, p. 37-46). No caminho aberto por Bolzano e Frege, ${ }^{8}$ encontra-se o embrião da tradição filosófica analítica, em especial, a temática da virada linguística (linguistic turn), e, com isso, a discussão sobre a Filosofia analítica da linguagem contemporânea.

A Filosofia analítica busca no rigor lógico, na precisão conceitual, na formalização do pensamento e na proximidade com as ciências empíricas seu ponto de partida. Ela surge no final do século XIX, a partir de Bolzano, Mach e Frege, que formam a chamada tradição semântica (MARCONDES, 2004/COFFA, 1991). Concomitante a eles, segue-se o trabalho conjunto de George E. Moore e Bertrand Russell, em oposição à tradição hegeliana inglesa e ao empirismo psicologista da época.

Segundo Hacker, (2007) podemos entender o período da Filosofia analítica do seguinte modo: a Filosofia analítica da linguagem se divide em quatro fases, as três primeiras deram primazia à sintaxe e à semântica, e a última deu primazia à pragmática. Na primeira fase, Moore, Russell e Wittgenstein ocuparam-se da associação e identificação

\footnotetext{
${ }^{7}$ Nobile, 2011 (trad. R. L. Heck).

${ }^{8}$ Evidentemente, este projeto também é influenciado por Kant, Leibnitz e Boole (PENCO, 2004).
} 
entre linguagem, pensamento e mundo. A teoria dos tipos, a teoria das descrições definidas e a teoria da denotação de Russell, seguidas das afirmações contundentes de isomorfismo entre pensamento, mundo e linguagem, contidas no Tractatus de Wittgenstein (1993), nomearam esta primeira fase de atomismo lógico. Fortemente influenciada pela primeira fase, a segunda ocupou-se de levar ao limite o método de análise lógica desenvolvido na primeira fase e é composta por filósofos como Ramsey, Braithwaite, Wisdom e Stebbing. A terceira fase, marcada pela postura antimetafísica e empirista, e vinculando fortemente o papel da Filosofia à ciência, muito frutífera nos ramos da Filosofia da ciência e da Filosofia da mente, é chamada de empirismo lógico e é representada pelo Círculo de Viena e seus seguidores pós-guerra. A quarta fase é chamada de Filosofia analítica de Oxford, a qual, liderada por Ryle e Austin, e contando com associados como Grice, Ayer e Strawson, tinha as seguintes premissas: a consideração propedêutica pela investigação do uso das palavras, quaisquer que fossem os problemas em questão; a metafísica não poderia ser feita sem consideração da dimensão linguística; a Filosofia seria concomitante, porém distinta das ciências.

Estes filósofos formam o cenário da Filosofia analítica e da virada linguística. Em uma breve recapitulação do que significa a virada linguística (reviravolta linguística ou viragem linguística), podemos dizer que é a pergunta que marca o início da Filosofia da linguagem contemporânea e o esforço dos filósofos em transpor o abismo entre sujeito e objeto, instituído no idealismo alemão, resultante do caráter ineliminável da mediação categorial subjetiva no conhecimento acerca das coisas (OLIVEIRA, 2006), Para superar este abismo, o pensamento filosófico empreendeu justamente a virada linguística (RORTY, 1967): todo o conhecimento é sempre formulado e verificado no interior de uma linguagem e esta, por sua vez, se encontra subordinada a categorias constitutivas fundamentais. Sob uma perspectiva filosófica, a linguagem é composta por três dimensões fundamentais (PENCO, 2004): a semântica, a sintaxe e a pragmática. A dimensão semântica governa a relação entre linguagem e os entes extralinguísticos, a sintaxe governa a relação entre os componentes da linguagem, e a pragmática governa a relação entre a linguagem e os falantes, ou seja, entre linguagem e uso. A partir da Filosofia analítica, podemos dizer que ocorrem duas viradas linguísticas: a virada semântica e a virada pragmática (OLIVEIRA, 2006). Os filósofos que de algum modo acataram as teses dos atomistas lógicos, fazem parte do primeiro momento da virada linguística, ou seja, o primeiro, segundo 
e terceiro grupos da Filosofia analítica, conforme citados acima, e que tinham como pressuposto a possibilidade da associação bem definida entre semântica e entidades extralinguísticas, e a da entre sintaxe e pensamento. Os filósofos que defendiam a primazia da pragmática, identificando o significado com o uso da linguagem e não com uma estrutura previamente dada, respondem ao segundo momento da virada linguística. Esta virada tem como ícone a obra de Wittgenstein Philosophische Untersuchungen ("Investigações filosóficas"), e é representada pelos filósofos do quarto grupo da Filosofia analítica, além de Searle, e outros.

Observando as características desse momento da Filosofia, não é difícil concluir que Platão esteve a todo tempo presente nos argumentos de Frege (2009, p. 283-298), Russell (HACKER, 2007) e até mesmo em Wittgenstein, em ambas as fases, tanto no Tractatus (clímax da primeira virada linguística), ${ }^{9}$ quanto nas Investigações filosóficas (clímax da segunda virada). ${ }^{10}$

Minha ideia é, entretanto, um pouco mais modesta e o paralelo mais restrito. Trazendo para os termos do diálogo de Platão do qual nos ocupamos, não parece muito forçosa a influência dos assuntos tratados no Crátilo sobre os temas da Filosofia analítica da linguagem. A questão se torna mais interessante, se levantarmos a hipótese de uma associação entre os argumentos que fazem parte do diálogo e a tentativa de solucionar a dicotomia entre a primazia semântica e a (primazia) pragmática da linguagem. Esta disputa encontrou tratamento nas teorias do significado, de cujos pioneiros David Lewis não só faz parte, como foi o primeiro a apontar uma saída para ela. O que pretendo provar com esta exposição é um duplo caráter de influência: um ascendente e outro descendente. $\mathrm{O}$ caráter ascendente (temporalmente) é a continuidade dos temas tratados no diálogo platônico pela Filosofia analítica da linguagem. $\mathrm{O}$ caráter descendente (temporalmente) é a associação das teorias do significado de Lewis com as teorias contidas no Crátilo, deduzidas por Norman Kretzmann à luz de algumas críticas a este intérprete. Quando Platão escreveu o Crátilo e nele condensou um cenário de discussão sobre a correção dos nomes, tivemos diante de nós, então, um retrato que foi redesenhado pela tradição filosófica ao longo dos séculos, sempre em uma elaborada escolha entre as concepções levantadas pelo filósofo grego.

\footnotetext{
${ }^{9}$ Rofena, 2013, p. 72-99.

${ }^{10}$ Rowett, 2013, p. 196-220.
} 
De modo geral, o que pretendo demonstrar é que Lewis se mantem fiel ao quadro desenhado por Platão, ao menos, pela ótica de Kretzmann. E justamente para tornar a hipótese interpretativa bem delimitada (uma discussão localizada), proponho a prioridade na interpretação de Kretzmann dos argumentos contidos no Crátilo. Esta escolha fornecerá uma reflexão sobre o modo como as questões contidas nesta obra parecem revividas à luz das teorias filosóficas contemporâneas da linguagem.

\section{Sistematização da correção por Kretzmann: naturalismo e con- vencionalismo no diálogo Crátilo $^{11}$}

Antes de tudo, é necessária uma justificativa pormenorizada sobre a escolha de Kretzmann como o principal intérprete na comparação entre os argumentos do diálogo platônico e as teorias do significado de Lewis. Em primeiro lugar, Kretzmann é o responsável por introduzir os termos naturalismo e convencionalismo na literatura sobre o Crátilo. Afinal, a associação entre a semântica e a pragmática implícita no papel do dialético ${ }^{12}$ nos fornece o indício de que há forte influência da linguística e da Filosofia da linguagem contemporâneas na interpretação do comentador. Em segundo lugar, a despeito das críticas que veremos a seguir, ele é um clássico na leitura contemporânea da obra. Portanto, representa o esforço inicial e o ponto de partida para a ideia da proximidade entre os assuntos abordados na obra e as questões filosóficas de centralidade linguística. Em terceiro lugar, boa parte das

\footnotetext{
${ }^{11}$ Salvo caso de referência explícita a outra fonte, as citações do Crátilo presentes no texto foram retiradas de Platão, Crátilo - trad. Celso O. Vieira.

${ }^{12}$ A pragmática a que me refiro diz respeito ao convencionalismo aceito por Sócrates, que, aliás, na leitura de Kretzmann, assemelha-se à concepção de pragmática de Carnap (1955, p. 33-47). Observe que Kretzmann diz (1971, p. 132): "Thus according to Plato's general theory we are capable of avoiding incorrect names - such as 'phlogiston' and 'monad' - to the extent to which science and philosophy (personified as 'the dialectician') have provided us with a correct conceptual schema". Esta proposta de construção de linguagens teóricas que introduzem e eliminam novas entidades para construir quadros conceituais que acompanhem o desenvolvimento da ciência é um projeto proposto inicialmente por Rudolph Carnap (1956, p. 205-221). Para uma melhor compreensão do modo como semântica e convencionalismo se relacionam em Carnap, e até mesmo para eventuais comparações com as teses de Sócrates, ver Runggaldier (RUNGGALDIER, 1984, p. 44-52).
} 
críticas dirigidas a ela incide sobre a etapa crítica da argumentação de Sócrates. Isto é, recaem sobre a interpretação que é feita das críticas de Sócrates, em especial, às teses de Hermógenes. Como será indicado adiante, a interpretação de Kretzmann sobre a estratégia de refutação de Sócrates a Hermógenes e a interpretação sobre o seu convencionalismo constituem as duas críticas de maior relevância para a exposição. Mas elas não influenciam no papel que as teorias elaboradas por Kretzmann têm na prova da hipótese de base deste artigo. Ainda assim, tendo em vista estas questões, resguardo possíveis contendas, de antemão, concordando com Ademollo sobre o caminho a seguir na interpretação das refutações de Sócrates a Hermógenes (ADEMOLLO, 2011, p. 62-68). Nem a versão negativa do contra-argumento (anti-covencionalista), nem a versão positiva (pró-naturalista) estão corretas. Afinal, o que está em jogo não é a escolha de uma das duas teses, mas a harmonia entre elas subsumida na proposta do nomoteta e do dialético.

Como vimos, Kretzmann foi o primeiro a nomear os argumentos de Hermógenes e Crátilo de convencionalista e naturalista (SEDLEY, 2003, p. 3). Em seu artigo "Plato on the correcteness of names", ele organiza os argumentos de Crátilo $\left(\left[\mathrm{C}_{1}\right],\left[\mathrm{C}_{2}\right]\right.$ e $\left.\left[\mathrm{C}_{3}\right]\right)$ e Hermógenes $\left(\left[\mathrm{H}_{1}\right]\right.$, $\left[\mathrm{H}_{1}{ }^{\prime}\right],\left[\mathrm{H}_{2}\right],\left[\mathrm{H}_{2}{ }^{\prime}\right],\left[\mathrm{H}_{3}\right]$ e $\left.\left[\mathrm{H}_{3}{ }^{\prime}\right]\right)$ em dois grupos: ${ }^{13}$

${ }^{13}$ Segue a passagem original de Kretzmann (1971, p. 126):

$\left[\mathrm{C}_{1}\right]$ For Each of the things that really exist there is a natural correctness of name.

$\left[\mathrm{C}_{2}\right]$ That is not a name which some people agreeing together to give as a name do give as a name, uttering a bit of their voice in accordance with agreement.

$\left[\mathrm{C}_{3}\right]$ Rather there exists naturally a kind of correctness of name that is the same for all, both Greeks and barbarians. (383A-B).

$\left[\mathrm{H}_{1}\right]$ No name exists by nature for any particular thing, but rather by the law and usage of those who use the name and call things by it.

$\left[\mathrm{H}_{1}{ }^{\prime}\right]$ Names are conventional, and they disclose things to those who established the convention and perceived the things beforehand.

$\left[\mathrm{H}_{2}\right]$ Whatever name someone imposes on a thing is the correct one; and if someone changes that name for another, the later one is no less correct than the earlier - just as when we change the name of our slave without the changed name being any less correct then the earlier one.

$\left[\mathrm{H}_{2}{ }^{\prime}\right]$ It makes no difference whether we adopt the existing convention or adopt an opposite one according to which what is now called large would be called small.

$\left[\mathrm{H}_{3}\right]$ There is no correctness of name other than convention and agreement.

$\left[\mathrm{H}_{3}{ }^{\prime}\right]$ The correctness of a name is convention. 
Grupo de argumentos de Crátilo: ${ }^{14}$

$\left[\mathrm{C}_{1}\right]$ Há uma correção dos nomes inerente à natureza de cada um dos seres.

$\left[\mathrm{C}_{2}\right]$ Um nome não seria isto que alguns, pronunciando parte de seu idioma, convencionaram usar para chamar.

$\left[\mathrm{C}_{3}\right]$ Haveria sim uma correção inerente aos nomes, a mesma para todos, Gregos ou estrangeiros.

Grupo de argumentos de Hermógenes:

$\left[\mathrm{H}_{1}\right]$ Nenhum nome é inerente à natureza de nada, ele segue apenas as normas e hábitos de quem o habilitou ao chamar (384d).

$\left[\mathrm{H}_{1}{ }^{\prime}\right]$ Nomes são convencionais, e eles revelam as coisas para aqueles que estabeleceram a convenção e as perceberam de antemão.

$\left[\mathrm{H}_{2}\right]$ Se alguém coloca um nome numa coisa, este está correto. Depois disso, se for mudado para um outro, e ninguém mais chamar pelo primeiro, o novo não vai ser menos correto que o anterior (384d).

[H $\left.{ }_{2}{ }^{\prime}\right]$ Não há diferença em adotar a convenção existente ou adotar uma oposta de acordo com a qual o que é chamado grande seria chamado pequeno.

$\left[\mathrm{H}_{3}\right]$ Não há outra correção dos nomes que convenção e acordo.

$\left[\mathrm{H}_{3}{ }^{\prime}\right]$ A correção do nome é convenção. ${ }^{15}$

Em razão desta divisão, Kretzmann (1971, p. 126-138) aponta duas questões, levantadas por Platão no diálogo, que exigem tratamentos distintos. Uma diz respeito aos nomes no sentido de esclarecer o que torna um nome ${ }^{16}$ correto ou incorreto, o comentador chamando esta pergunta de

\footnotetext{
${ }^{14}$ Platão, Crátilo (383a-b) - trad. Celso O. Vieira.

${ }^{15}\left[\mathrm{H}_{1}{ }^{\prime}\right],\left[\mathrm{H}_{2}{ }^{\prime}\right],\left[\mathrm{H}_{3}\right]$ e $\left[\mathrm{H}_{3}{ }^{\prime}\right]$ são traduções livres do texto de Kretzmann. O restante do argumento foi retirado diretamente do diálogo (Platão, Crátilo - trad. Celso O. Vieira). ${ }^{16} \mathrm{O}$ conceito "nome" (ónoma) discutido ao longo deste texto deve ser entendido como palavra, que contém nomes próprios, nomes de classes de coisas e nomes abstratos (ACKRILL, 1997, p. 36).
} 
certification question. A outra questão levanta a condição de determinar se certo nome é adequado para aquilo a que queremos nos referir por ele, sendo que a esta pergunta ele nomeia de demonstration question. Para satisfazer à primeira, Kretzmann interpreta uma teoria geral da correção dos nomes com escopo de aplicação à toda linguagem e para satisfazer à segunda, ele interpreta uma teoria especial da correção dos nomes, contendo princípios particulares, com escopo relativo às línguas particulares. ${ }^{17}$

Para Kretzmann, as afirmações iniciais de Hermógenes defendem um convencionalismo forte que afirma não haver marca ou sinal especial para um nome. Para ele, a visão é subjetivista e inconsistente (385d; 431b-c), ${ }^{18}$ e tem por objetivo principal apresentar o problema da imposição dos nomes. ${ }^{19}$ Entretanto, como aponta Richardson (1976, p. 136-137), neste momento do diálogo, Sócrates está apenas levantando o significado do convencionalismo de Hermógenes, e suas falas iniciais não são condição suficiente para um argumento. Além disso, Hermógenes, de certo modo, concorda de antemão com a possibilidade de nomes falsos. Daí, um dos equívocos na interpretação de Kretzmann, o de que Sócrates estaria concordando com Hermógenes para empreender um argumento por redução ao absurdo (KRETZMANN, 1971, p. 127). Isto nos parece realmente inadequado; sendo, entretanto, indiferente ao objetivo deste estudo. Pois, como veremos na conclusão, a teoria convencionalista

\footnotetext{
${ }^{17}$ Kretzmann, 1971, p. 127: "The theory developed in response to the demonstration question is perfectly general in its principles, but the application of the principles yields different results for each language".

${ }^{18}$ Kretzmann, 1971, p. 127 (nota de rodapé 4).

${ }^{19}$ De acordo com Barney, o convencionalismo que Hermógenes apresenta não envolve apenas a questão da imposição dos nomes. A tese dele se divide em duas: A questão da imposição ou nomeação, que a intérprete chama de batismo, e a questão do emprego de nomes. Ou seja, a primeira é a prática (ação) de nomear (ethémenn) (denominar) algo, e a outra é a prática (ação) de chamar (kalê̂n) algo por tal nome. $\mathrm{O}$ ato de nomear, ou batismo, segundo Barney, pode ser coletivo ou individual. $\mathrm{O}$ ato de chamar, não. Ele depende de dois ou mais falantes. Já a questão da correção dos nomes da perspectiva do convencionalismo de Hermógenes ocorre no ato de chamar corretamente algo pelo nome pelo qual foi denominado, isto é, se eu batizo algo com o nome $\mathrm{N}$, isso é correto se todos chamarem este algo por $\mathrm{N}$, caso contrário não e teremos assim um nome falso. Daí Hermógenes concordar com a possibilidade de nomes falsos (BARNEY, 1997, p. 143-162).
} 
entendida por Kretzmann será revisada à luz das críticas de Rachel Barney feitas a ele.

Após a fala de Sócrates, Hermógenes é levado a concordar que há certa "existência estável" nos nomes (386d-e). Nomear é algo objetivo, e realizar a atividade não é ato ao acaso, mas isto deve ser feito utilizando-se as ferramentas corretas (385e-387b). Como falar é uma ação complexa (387b-c) e nomear está contido na fala, nomear é também uma ação. Portanto, deve haver um método e uma ferramenta (387d), e quem deve nomear, deve nomear com algo (387e), e o nome também é como uma ferramenta (388a). De tal modo que Kretzmann afirma que a ação de nomear é composta de: ${ }^{20}$

1) Os nomes que são ferramentas.

2) Os objetos que são as coisas que realmente são.

3) E duas tarefas (o método) executadas ao nomearmos algo:

a) Ensinar, comunicar a verdade sobre coisas reais.

b) Informar algo aos outros e distinguir as coisas como são, pois [o nome] é um tipo de instrumento informativo e distintivo da existência (388b-c).

Os elementos 3.a e 3.b são entendidos por Kretzmann como duas atividades: 1. Taxonomia e 2. Instrução (ensinar).

O impasse que surge é a precedência entre estas tarefas ao nomearmos. Ensinar pressupõe o uso da linguagem contendo nomes corretos, logo a taxonomia deve preceder na atividade de nomear e deve dispor de um critério adequado de correção (388d).

\subsection{Taxonomia}

Conseguimos os nomes pela própria prescrição da natureza das coisas (387d) e o critério de correção é obtido a partir do método de construção do modelo ideal pelo nomoteta (389-390). Nas palavras de Kretzmann, a atividade do nomoteta é "algo similar à combinação

${ }^{20}$ Kretzmann, 1971, p. 128. 
interativa do bom uso do Inglês e o dicionário Oxford de Inglês": 21 Destarte, ele nos oferece uma definição não alegórica da teoria geral da correção dos nomes:

[1] O nome atual de N é um nome correto (no sentido de que deve haver justamente tal nome em uso) se e somente se $\mathrm{N}$ é uma personificação em sons e sinais do modelo correto do nome de xs; isto é, (a) há xs e (b) N é usado ou tem a intenção de ser usado como um nome para xs, e (c) há um modelo de nome correto de xs.

[2] Há um modelo de nome correto de xs, se e somente se (a) há uma Forma de $x,{ }^{22} \mathrm{e}(\mathrm{b})$ há um nome logicamente próprio da Forma que está personificada em sons ou sinais.

[3] A correção do modelo de nome correto de xs é natural se copia a Forma de x em, pelo menos, as seguintes extensões: (a) inclui características essenciais suficientes de xs - características constitutivas da Forma de $\mathrm{x}$ - portanto não poderia ser também um nome para outra Forma, e (b) exclui todas as características individuantes de qualquer $\mathrm{x}$ singular e todas as características diferenciadoras de qualquer subgrupo de xs. ${ }^{23}$

${ }^{21}$ Barney, 1997, p. 129: “(...) something like the interacting combination of good English usage and the Oxford English dictionary" (trad. R. Heck).

${ }^{22}$ Neste ponto, Ackrill parece discordar ao apresentar que há dois tipos de discurso: o ordinário, ao falarmos de coisas ordinárias, e o filosófico, no qual falamos sobre significados e conceitos. O primeiro estaria subordinado ao fluxo no sentido heraclitiano, e o segundo, subordinado às Formas platônicas. A despeito desta divisão ontológica, que obviamente exigiria uma subdivisão semântica, a distinção não parece afetar o teor eminentemente linguístico da nossa exposição, já que ambas as ontologias são acessíveis via linguagem (ACKRILL, 1997, p. 49-52).

${ }^{23}$ Kretzmann, 1971, p. 131: "[1] The actual name $N$ is a correct name (in the sense that there ought to be just such a name in use) if and only if $N$ is an embodiment in sound and marks of the model correct name of $x \mathrm{~s}$; that is, (a) there are $x \mathrm{~s}$, and (b) $N$ is used or intended to be used as a name for $x \mathrm{~s}$, and (c) there is a model correct name of $x \mathrm{~s}$.

[2] There is a model correct name of $x$ s if and only if (a) there is a form of $x$, and (b) there is a logically proper name of that form which is embodied in sound or marks. [3] The correctness of the model correct name of $x \mathrm{~s}$ is natural in that it copies the Form of $x$, at least to the extent that (a) it includes enough essential features of $x \mathrm{~s}$ - features constitutive of the form of $x$ - so that it could not also be a name of some other Form, 
Há, portanto, três momentos de correção: do nome, da relação e do modelo.

O nome é correto se e somente se:

(a) Há algo designável pelo nome.

(b) O nome está em uso para o que é designável.

(c) Há um modelo de nome correto para o nome em questão. ${ }^{24}$

A relação entre nome e modelo é correta se e somente se:

(a) O designável tem Forma.

(b) Há um nome logicamente próprio da Forma ${ }^{25}$ do designável e ele é instanciável em sons ou sinais.

O modelo é correto na cópia da forma se e somente se:

(a) Há características constitutivas da Forma do designável e elas excluem a possibilidade de designar qualquer outra Forma.

(b) Ele não inclui nenhuma característica de nenhum particular designável pelo nome.

Devemos levar em consideração que a correção do modelo se desdobra em condições puramente lógicas. Este modelo é ideal, no sentido de que ele é o ponto de partida para a construção dos vocábulos das línguas, o modelo mesmo não sendo "personificável" (embodiment)/ instanciável por nenhuma língua particular. Já a relação de modelagem com vistas à correção do nome, tanto se ocupa da composição dos sons e signos das palavras, quanto da existência da correção e incorreção

and (b) it excludes all individuating features of any single $x$ and all differentiating features of any sub-group of $x \mathrm{~s}$ ".

${ }^{24}$ A decisão pelo nome possuir um modelo de nome correto ou incorreto pertence ao dialético (KRETZMANN, 1971, p. 132).

${ }^{25}$ I.e. há um tipo objetivamente real, do qual os particulares designáveis são participantes (KRETZMANN, 1971, p. 131). 
dos nomes atuais nas linguagens (390d-e) ${ }^{26}$ e sua constante utilização é orientada pela Forma do designável.

Há ainda outra tarefa levada a cabo pelo personagem Sócrates no diálogo, que Kretzmann identifica como a teoria especial da correção dos nomes: "Uma tentativa de estabelecer critérios e técnicas para determinar o grau de naturalidade com a qual um atual nome correto instancia o modelo correto do nome" (KRETZMANN, 1971, p. 134).

Em (393a) Sócrates compara os nomes de Astyánax e Héctor e conclui que há neles algo em comum. Em seguida, Sócrates afirma que $^{27}$ 'tanto faz que a mesma coisa seja significada por este ou aquele conjunto de sílabas; e tampouco importa que seja acrescentada ou tirada uma letra, desde que a entidade forte da coisa seja manifesta no nome". $\mathrm{Na}$ tradução, forte ${ }^{28}$ é traduzido de dýnamis. ${ }^{29}$ É esta função que deve ser preservada na palavra, salvo as modificações que fazemos nela, como no programa etimológico ensaiado por Sócrates. Assim, conhecer sua função é conhecer o nome e sua dýnamis: "Quem toma consciência dos nomes averigua do mesmo modo, sem ser dissuadido caso alguém adicione ou subtraia uma letra, ou até restabeleça, com letras completamente diferentes, o princípio ativo do nome [dýnamis]" (394b). O que leva Kretzmann a afirmar que a similaridade entre diferentes palavras (e.g. Astíanax e Heitor - 394b-c) não é etimológica, mas semântica (KRETZMANN, 1971, p. 134). De fato, ela é uma similaridade que

\footnotetext{
${ }^{26}$ Kretzmann, 1971, p. 130: “An attempt to establish criteria and techniques for determining the degree of naturalness with which a correct actual name embodies the model correct name" (trad. R. Heck).

${ }^{27}$ Platão, Crátilo (393d) - trad. Celso O. Vieira: "Se o mesmo vem assinalado com estas ou aquelas sílabas, não é nada, nem se há adição ou subtração de alguma letra. Tudo isso não é nada se a existência característica da coisa vem evidenciada no nome". ${ }^{28}$ Platão, Crátilo (393d) - trad. Harold N. Fowler: "And whether the same meaning is expressed in one set of syllables or another makes no difference; and if a letter is added or subtracted, that does not matter either, so long as the essence of the thing named remains in force and is made plain in the name".

${ }^{29}$ Como aponta Figueiredo na nota de rodapé 20 à sua tradução do Crátilo de Platão (2001), dýnamis ocorre quatro vezes na fala de Sócrates e simultaneamente ligado aos nomes e às drogas. Pois a força/poder provém da mesma palavra dýnamis em sua tradução.
} 
une fonética e semântica, e que veio a inspirar os Estoicos na criação do naturalismo composto por nomes e sílabas (lékta). ${ }^{30}$

Esta forma de tratamento constitui a teoria especial da correção dos nomes como resposta à demonstration question. Toda forma de levantamento da dýnamis de um nome deve ser feita com base em uma língua específica, ou seja, aplicável ao grego ou a outras línguas em particular (401c), embora estejam excluídos os nomes próprios, uma vez que dados às pessoas sem muito critério (397a). Esta teoria especial, segundo Kretzmann, é composta por 2 estágios e classifica três tipos de entidades no interior de uma língua especifica.

No primeiro estágio:

a) Os nomes primários: palavras que dão origem aos nomes secundários.

b) Os nomes secundários: palavras derivadas dos nomes primários.

O curso das etimologias desenvolvidas por Sócrates exemplifica este estágio. Ele encontra o momento inicial de transição para o segundo estágio quando Sócrates afirma ser improvável traçar uma etimologia das palavras "fogo", "água" e "cão", pois suas raízes estão na língua dos Frígios (410a). A transição se completa no diálogo quando, por um lado, Sócrates se depara com a impossibilidade de explicar os primeiros nomes (palavras primárias), dada a antiguidade de sua criação (421c-d), e, por outro, com o problema de um regressus ad infinitum ao perguntarmos pelas origens das palavras que explicam as palavras, ou melhor, pelas origens das palavras primárias se usássemos outras palavras para explicálas (421d-e). Eis então que Sócrates lança mão do termo stoikheîa, que fundamenta o que Kretzmann chamará de Proteronyms [Proterônimos]. ${ }^{31}$

No segundo estágio temos:

a) Proteronyms: os elementos que compõem um dado nome primário. Eles devem ter duas características:

i. Ser diferente de um nome. I.e. não ser outro nome.

ii. Ser o componente do nome.

${ }^{30}$ Long, 2005, p. 45-46.

31 Termo cunhado pelo próprio Kretzmann (trad. R. Heck). 
Para Kretzmann (1971, p. 135), Sócrates conclui que a procura por tais elementos fundamentais não chega a um resultado positivo, nem através da imitação dos sons das coisas, nem tampouco das letras e sílabas que compõem os nomes (423c), ainda que a possibilidade permaneça em aberto para aquele que pudesse imitar por meio de letras e sílabas a existência de cada coisa, o nomoteta (423e-424a). Um exemplo disto é o cuidadoso sistema de associação entre as letras e as Formas, em que as primeiras mimetizam as segundas na medida em que a boca gesticula para emitir os sons correspondentes (426c-427d). ${ }^{32}$

Dadas as dificuldades do primeiro e do segundo estágio, não é possível levar adiante a teoria especial da correção dos nomes. Pois como poderíamos ter certeza de que os nomes que foram cunhados de fato estão em conformidade com as coisas que eles designam, já que esta teoria especial se aplica apenas a línguas particulares e atuais? Além disso, como resolver quando, no regresso em busca das origens, nos deparamos com raízes bárbaras [estrangeiras] das palavras além da distância temporal entre quem nomeou e quem pergunta pela correção do nome?

Assim, dadas as impossibilidades do segundo estágio e, por consequência, a perda da importância filosófica (da busca pelo fundamento) do primeiro estágio, resta a Sócrates abandonar este projeto de análise e redução da linguagem (436e-438a) e assumir a importância da convenção.

Antes disto, Kretzmann (1971, p. 137) chama a atenção para uma passagem do diálogo ${ }^{33}$ que parece indicar como seria possível completar o projeto da teoria especial da correção dos nomes:

\footnotetext{
32 Esta correspondência ocorre, como aponta Kretzmann, devido à função principal das linguagens em uso, que é imitar as características essenciais do cosmos de Heráclito - o mundo sensível em constante fluxo.

${ }^{33}$ Platão, Crátilo (424e-425a) - trad. Maria João Figueiredo: "Pois julgo que cada imagem necessita de uma cor própria. E será da mesma maneira que nós aplicaremos os elementos às coisas, um elemento a uma coisa, quando nos parecer necessário, ou muitos elementos juntos, formando aquilo que se chama sílabas; e combinaremos as sílabas, a partir das quais se formarão os nomes e os verbos, construiremos uma coisa ainda maior e mais bela e mais completa; da mesma maneira que atrás fizemos um animal por meio da pintura, agora construiremos o discurso por meio da arte de nomear, ou retórica, ou a arte que for".
} 
Acho que a opinião é que cada representação possui seu devido pigmento. Assim também faremos com os elementos em relação às coisas, um por um, na devida opinião, ou fazendo composições que são chamadas sílabas. Desse modo serão compostas as sílabas das quais se compõem os nomes e verbos. Então, mais uma vez, a partir de nomes e verbos, vamos reunir algo grande, charmoso e completo, qual um retrato na pintura, ou seja, uma fala na onomástica, retórica ou qualquer que seja essa técnica (424e-425a).

Ora, Kretzmann ressalta ainda que este projeto de Platão seria o protótipo da caracteristica universalis de Leibnitz, e da Begriffsschrift de Frege. Eu adicionaria o isomorfismo da sintaxe lógica no Tractatus Logico-Philosophicus de Wittgenstein, especialmente quando somando os dois parágrafos anteriores (424c-e) ao que foi citado. Pois, além do projeto de uma linguagem isomórfica às coisas, Platão nos apresenta como analogia ao projeto o modo como um pintor compõe diferentes cores a fim de reproduzir com fidelidade a coisa na tela. ${ }^{34}$

\subsection{Instrução}

Dito isto, a convenção se torna o elemento final de consideração do diálogo e, junto com ele, a segunda tarefa a ser executada ao nomearmos algo: a instrução (ensinar). Nas palavras de Kretzmann: "A consideração do nome sklerótés (dureza) em 434b-435a fornece o argumento mais forte para a dependência da instrução ou da comunicação geralmente em relação à convenção". ${ }^{35}$

Há aí dois objetivos apontados por Kretzmann, o primeiro é dizer que a instrução é totalmente dependente da convenção, i.e. usar os nomes tem o propósito de instruir (428e) e é a partir da instrução (ensino) que conhecemos os nomes e, por conseguinte, as coisas (435d). O segundo objetivo em delimitar o papel da convenção é afirmar que ela é construída

\footnotetext{
${ }^{34} \mathrm{O}$ que, para mim, segue-se como inspiração direta da função isomórfica entre linguagem e mundo, e da teoria pictórica no Tractatus.

${ }^{35}$ Kretzmann, 1971, p. 137: "The consideration of the name sklerótes (hardness) in 434b-435a provides the most forceful argument for the dependence of instruction, or communication generally on convention".
} 
por meio da relação entre falantes e, também, pelo menos, por meio da relação entre os nomes e as coisas nomeadas. Logo após mostrar a inconsistência na etimologia das letras, Sócrates diz:

Pois, a partir do costume ${ }^{36}$ e da convenção, aconteceria alguma evidenciação tanto com as letras iguais quanto com as desiguais. Mesmo que o costume são seja bem uma convenção, ainda assim não seria bom falar que a igualdade é uma evidência, mas sim o costume. Pois este, aparentemente, evidencia com o igual e com o desigual. Uma vez que consentimos nisso, Crátilo, pois tomo o seu silêncio por consentimento, surge a obrigatoriedade de alguma convenção ou costume vir junto com a evidenciação do que temos no intelecto ao falarmos. Na sequência, meu caro, se desejar, podemos seguir com os números. Como você acha que os nomes vão trazer postos em cada um deles a igualdade com os números, caso você não permita a confirmação de que também a convenção tem autoridade sobre a correção dos nomes? Eu também ficaria satisfeito que houvesse um princípio de igualdade entre nomes e coisas. Porém, como no caso de Hermógenes, a atração por igualdade não seria verdadeiramente consistente. Pois se faz obrigatório aceitar o fardo da convenção na correção dos nomes (435a-c).

A inevitabilidade da aceitação da convenção significa que Platão, através desta fala de Sócrates e da passagem 388d-399a, propõe um caminho que una a técnica de construção das palavras do nomoteta (o artífice que cria o instrumento) à técnica de emprego das palavras do dialético (o artífice que usa o instrumento), já que este último, por meio de certo grau de aceitação da convenção, se ocupa em instruir outras pessoas, informando algo aos outros e distinguindo as coisas como são. ${ }^{37}$

\footnotetext{
${ }^{36}$ Kretzmann traduz utiliza "usage" (uso, emprego, hábito) no lugar da palavra "costume".

${ }^{37}$ Platão, Crátilo (388b) - trad. Celso O. Vieira.
} 


\section{As teorias do significado de David Lewis:}

Ao falarmos sobre teorias do significado, em especial após a virada linguística no pensamento filosófico contemporâneo, nos deparamos, hoje, com dois tipos de teorias: as teorias semânticas e as teorias fundacionais do significado. A junção de ambas constitui a dimensão construtiva e significativa da linguagem (a pragmática e a semântica da linguagem). Um principal proponente da distinção entre estas duas teorias no interior da teoria do significado é David Lewis, cujo comentário será nosso ponto de partida:

Eu distingo dois tópicos: primeiro, a descrição de possíveis linguagens ou gramáticas como sistemas semânticos abstratos por meio dos quais símbolos são associados com aspectos do mundo; e, segundo, a descrição dos fatos psicológicos e sociológicos por meio dos quais um destes sistemas semânticos abstratos em particular é aquele utilizado por uma pessoa ou população. ${ }^{38}$

O primeiro tópico do qual fala Lewis é a teoria semântica do significado, sua tarefa sendo sistematizar a pergunta: "Qual o significado desta ou daquela expressão?", ou, em outras palavras, "Como ocorre a especificação do significado dos componentes em um sistema simbólico?". O segundo tópico é a teoria fundacional do significado, que busca explicar os critérios que levam uma pessoa ou grupo a dar aos símbolos de sua linguagem os significados que eles têm.

Para ilustrar estas teorias, suponhamos que um sujeito observa o emprego de uma série de palavras e gestos trocados por um grupo de falantes de uma língua desconhecida; o observador deve:

${ }^{38}$ Lewis, 1970, p. 19: "I distinguish two topics: first, the description of possible languages or grammars as abstract semantic systems whereby symbols are associated with aspects of the world; and, second, the description of the psychological and sociological facts whereby a particular one of these abstract semantic systems is the one used by a person or population" (trad. R. Heck). 
1) (a) Perguntar pelo significado de cada palavra e estabelecer um método de significação delas, usando como parâmetro algum modelo tipológico de classificação das unidades do sistema simbólico (nomes, proposições, atitudes proposicionais, etc.).

1) (b)Em seguida, explicar a contribuição que as unidades do sistema simbólico fazem para a determinação dos valores de verdade em todas as sentenças (o discurso) nas quais elas ocorrem (LEWIS, 1970, p. 22).

2) Por fim, perguntar pelos critérios que justificam as expressões da linguagem terem tais e tais propriedades, serem usadas em tais e tais situações, e de tais e tais maneiras. Tipos de critérios como conteúdo mental, convenção, regularidade, etc. são comumente utilizados para justificar esta relação.

No caso de Lewis, as observações de 1a e 1 b devem ser aplicadas em um sentido amplo, seu escopo não envolvendo uma língua específica, mas a linguagem em um sentido abstrato (um sistema linguístico qualquer). Já no caso de 2 , devemos sempre partir de uma língua particular.

No caso 1a do nosso exemplo, Lewis estabelece uma gramática de estrutura frasal livre de contexto (context-free) que possui como categorias básicas a sentença, o substantivo e o nome; regras de derivação para outras categorias; e regras de composição frasal. E com base neste modelo que ele estabelece seus critérios para uma teoria semântica como função de indexação de oito elementos extragramaticais ${ }^{39}$ aos componentes gramaticais da linguagem, que ele denomina de intensões apropriadas,${ }^{40}$ o que implica em 1b: as sentenças são indexadas a valores

${ }^{39}$ Lewis, 1970, p. 25: "Thus an index is tentatively any octuple of which the first coordinate is a possible world, the second coordinate is a moment of time, the third coordinate is a place, the fourth coordinate is a person (or other creature capable of being a speaker), the fifth coordinate is a set of persons (or other creatures capable of being an audience), the sixth coordinate is a set (possibly empty) of concrete things capable of being pointed at, the seventh coordinate is a segment of discourse, and the eight coordinate is an infinite sequence of things".

${ }^{40}$ Lewis, 1970, p. 23: "A function which yields as output an appropriate extension when given as input a package of the various factors on which the extension may depend. We will call such an input package of relevant factors an index; and we will call any 
de verdade; nomes a coisas; e substantivos a conjuntos. O significado se dá a partir da composição dos elementos gramaticais, como demonstrado por Lewis:

Uma vez que tenhamos identificado significados com marcadores de frase semanticamente interpretados, se torna natural reconstruir as regras de estrutura frasal da gramática categorial em conjunto com as regras de projeção correspondentes, como condições de boa formação para significados. ${ }^{41}$

E a significação de estruturas complexas da linguagem é função da significação das expressões constituintes, o que implica em uma teoria referencial da linguagem como uma teoria subordinada à semântica. Resumidamente, há uma armação lógico-semântica que justifica a relação de significação entre expressões complexas, expressões simples e o mundo.

No caso 2 do nosso exemplo, Lewis estabelece o critério de regularidade como fundamentação à convenção: "As convenções da linguagem são um mito. A sóbria verdade é que nosso uso da linguagem se conforma a regularidades" ${ }^{42}$ Ele entende que a regularidade é o critério que permite a percepção de similaridade entre os participantes das práticas coordenadas ${ }^{43}$ e, com isso, a execução de certos padrões de ações com base no resultado satisfatório de uma classe de problemas anteriormente enfrentados por um determinado indivíduo ou grupo. As convenções explícitas ou tácitas são resultado de ações coordenadas em grupo, o uso da linguagem sendo uma delas, quando coordenadas com base na regularidade de situações recorrentes. A definição dada é a seguinte:

function from indices to appropriate extensions for a sentence, name, or common noun an intension".

${ }^{41}$ Lewis, 1970, p. 33: "Once we have identified meanings with semantically interpreted phrase markers, it becomes natural to reconstrue the phrase-structure rules of categorial grammar, together with the corresponding projection rules, as conditions of wellformedness for meanings" (trad. R. Heck).

${ }^{42}$ Lewis, 2002, p. 2: "The conventions of a language are a myth. The sober truth is that our use of language conforms to regularities".

${ }^{43}$ Prática coordenada é qualquer atividade conjunta com 2 ou mais participantes que buscam um equilíbrio coordenado; este por sua vez é a ação conjunta para a resolução da atividade em que cada indivíduo desempenha um papel diferente ou igual na atividade. 
Uma regularidade $\mathrm{R}$ no comportamento dos membros de uma população $\mathrm{P}$ quando são agentes em uma situação $\mathrm{S}$ é uma convenção, se e somente se, em qualquer instância de $\mathrm{S}$ entre os membros de P: (1) Todos estão de acordo com R; (2) Todos esperam que todos estejam de acordo com R; (3) Todos preferem estar de acordo com $\mathrm{R}$ sob a condição de que outros estejam, uma vez que $\mathrm{S}$ é um problema de coordenação e a conformidade uniforme com Ré um equilíbrio de coordenação próprio em $\mathrm{S} .{ }^{44}$

Grosso modo, a convenção é uma atividade relativamente formal, originada pela concordância entre os participantes. No caso da linguagem, a relação ocorre entre o comunicador e a plateia, através de um sistema de signos que se origina dos sinais emitidos pelo comunicador (que é orientado por um plano de ação contingente de regularidade) e das interpretações dos membros da plateia (que são orientados por planos de reação contingentes de regularidade), este processo sendo uma via dupla em que o comunicador e a plateia são constantemente retroalimentados pelas ações uns dos outros com vistas ao equilíbrio coordenado para a resolução do problema.

Os sucessivos processos descritos acima originam uma convenção de sinais, e, por consequência, um sistema convencional de sinais:

Nós podemos definir uma convenção de sinais como qualquer convenção por meio da qual os membros de uma população $\mathrm{P}$, que estão envolvidos como comunicadores ou audiência em um certo problema assinalado $\mathrm{S}$, fazem as suas partes de um sistema de sinais $<\mathrm{Fc}, \mathrm{Fa}>$ agindo de acordo com seu respectivo

\footnotetext{
${ }^{44}$ Lewis, 2002, p. 46: "A regularity $R$ in the behavior of members of a population $P$ when they are agents in a current situation $S$ is a convention if and only if, in any instance of $S$ among members of $P$,

(1) Everyone conforms to $R$;

(2) Everyone expects everyone else to conform to $R$;

Everyone prefers to conform to $R$ on condition that the others do, since $\mathrm{S}$ is a coordination problem and uniform conformity to $R$ is a proper coordination equilibrium in $S^{\prime \prime}$ (trad. R. Heck).
} 
plano de contingência. Se tal convenção existe, nós também chamamos $<\mathrm{Fc}, \mathrm{Fa}>$ um sistema de sinais convencional. ${ }^{45}$

E, por conseguinte, uma determinada linguagem. Vejamos, agora, como podemos associar estas teorias àquelas contidas no Crátilo, segundo a leitura de Kretzmann, e que deduções, críticas e revisões podem ser feitas disto.

\section{Aproximação entre teorias: o Platão de Kretzmann e Lewis}

Estabelecida a sistematização do pensamento de David Lewis e a sistematização do Crátilo por Kretzmann, iremos comparar as duas teorias e observar se, do modo como foi exposto o diálogo de Platão, é possível anteciparmos uma teoria do significado no sentido amplo, i.e., contendo uma teoria da semântica e uma teoria fundacional do significado e, adicionalmente, uma teoria da referência.

Chamamos de Teoria Semântica (TS ${ }^{46}$ uma teoria que emparelha as expressões de uma linguagem com as entidades que as expressões significam.

Chamamos de Teoria da Referência (TR) uma teoria que emparelha expressões com a contribuição que estas expressões fazem para a determinação do valor de verdade das sentenças/discurso nos quais elas ocorrem.

Chamamos de Teoria Fundacional do Significado (TFS) os fatos em virtude dos quais as expressões das linguagens naturais passam a ter as propriedades semânticas que atualmente têm.

\footnotetext{
${ }^{45}$ Lewis, 2002, p. 135: "We can define a signaling convention as any convention whereby members of a population $\mathrm{P}$ who are involved as communicators or audience in a certain signaling problem $\mathrm{S}$ do their parts of a certain signaling system $<\mathrm{Fc}, \mathrm{Fa}>$ by acting according to their respective contingency plans. If such a convention exists, we also call $<\mathrm{Fc}, \mathrm{Fa}>$ a conventional signaling system".

${ }^{46}$ Iremos desconsiderar propositalmente a distinção entre teoria semântica proposicional e teoria semântica não-proposicional devido ao caráter intermitente na discussão do Crátilo, o que não impede um estudo posterior de aproximação com uma teoria semântica não-proposicional na referida obra.
} 


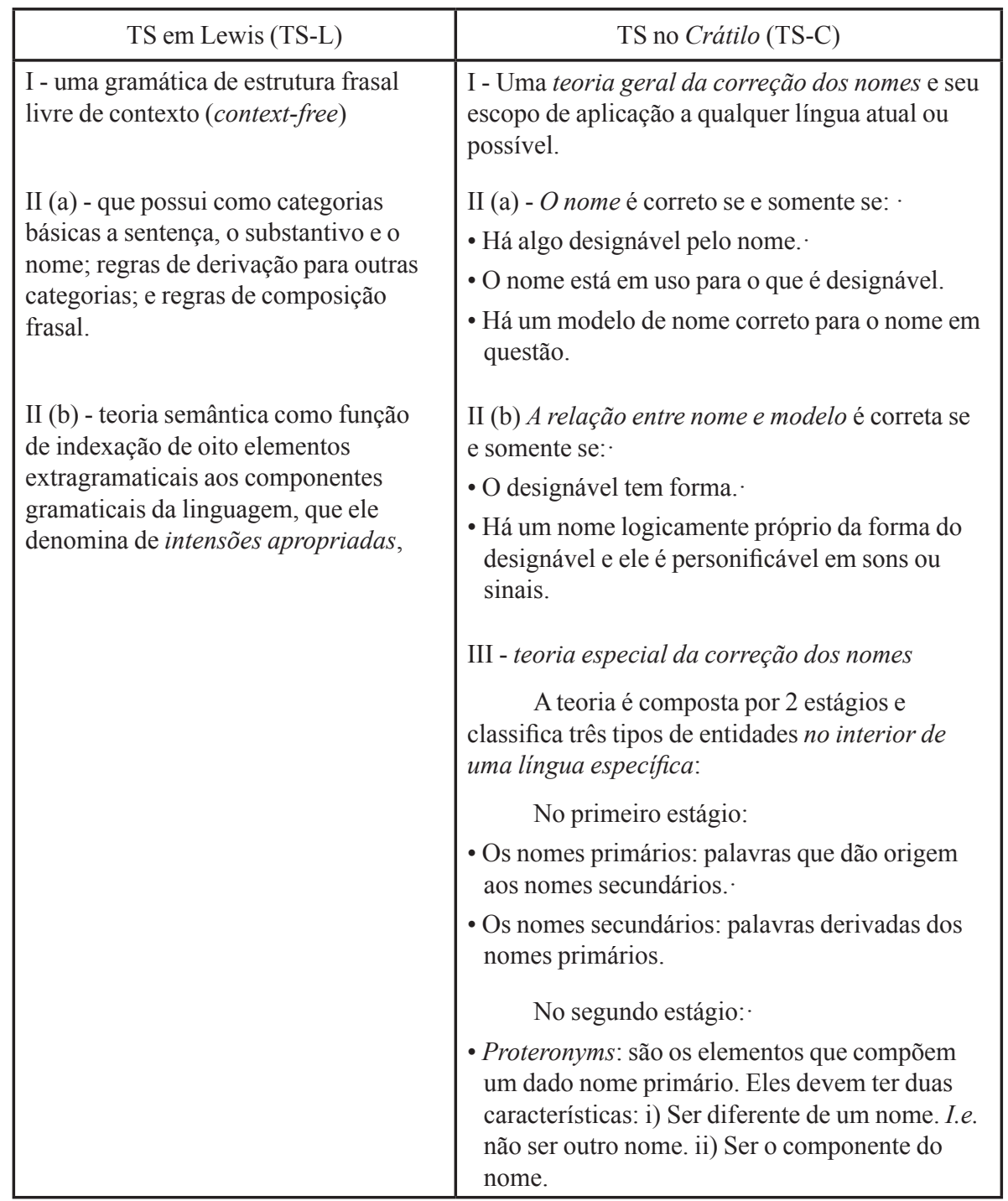




\begin{tabular}{|c|c|}
\hline TR em Lewis (TR-L) & TR no Crátilo (TR-C) \\
\hline $\begin{array}{l}\text { I - as sentenças são indexadas a } \\
\text { valores de verdade; nomes a coisas; e } \\
\text { substantivos a conjuntos. A referência } \\
\text { se dá a partir da composição dos } \\
\text { elementos gramaticais. }\end{array}$ & $\begin{array}{l}\text { I - O modelo é correto na cópia da forma se e } \\
\text { somente se: } \\
\text { - Há características constitutivas da forma do } \\
\text { designável e elas excluem a possibilidade de } \\
\text { designar qualquer outra forma. } \\
\text { - Ele não inclui nenhuma característica de } \\
\text { nenhum particular designável pelo nome. }\end{array}$ \\
\hline TFS em Lewis (TFS-L) & TFS no Crátilo (TFS-C) $)^{47}$ \\
\hline $\begin{array}{l}\text { A convenção é uma atividade } \\
\text { relativamente formal, originada pela } \\
\text { concordância entre os participantes. } \\
\text { No caso da linguagem, a relação ocorre } \\
\text { entre o comunicador e a plateia, através } \\
\text { de um sistema de signos que se origina } \\
\text { dos sinais emitidos pelo comunicador } \\
\text { e das interpretações dos membros da } \\
\text { plateia, este processo sendo uma via } \\
\text { dupla em que o comunicador e a plateia } \\
\text { são constantemente retroalimentados } \\
\text { pelas ações uns dos outros com vistas ao } \\
\text { equilíbrio coordenado para a resolução } \\
\text { do problema. }\end{array}$ & $\begin{array}{l}\text { "Surge a obrigatoriedade de alguma convenção } \\
\text { ou costume vir junto com a evidenciação do } \\
\text { que temos no intelecto ao falarmos. (435b) (...) } \\
\text { Eu também ficaria satisfeito que houvesse um } \\
\text { princípio de igualdade entre nomes e coisas. } \\
\text { Porém, como no caso de Hermógenes, a atração } \\
\text { por igualdade não seria verdadeiramente } \\
\text { consistente. Por isso se faz obrigatório aceitar } \\
\text { o fardo da convenção na correção dos nomes". } \\
(435 c)\end{array}$ \\
\hline
\end{tabular}

Antes das aproximações teóricas, faz-se necessário reformular a TSF-C para que comporte as críticas de Rachel Barney. Como apresentado na nota 42, a convenção de Hermógenes ocorre da seguinte forma: há a imposição do nome (ethémen - ato de nomear) e o emprego do nome (kaleîn - chamar pelo nome; uso do nome). Nomear pode ser individual ou coletivo, chamar só pode ser coletivo. Desta forma,

\footnotetext{
${ }^{47}$ Platão, Crátilo (435 c) - trad. Maria João Figueiredo: “É de certa maneira necessário que a convenção e o costume contribuam para mostrar aquilo que temos em mente quando falamos”. Platão, Crátilo (435b) - trad. Maria João Figueiredo: “(...) Por mim agrada-me aquela tese segundo a qual os nomes são, na medida do possível, semelhantes às coisas; mas receio que, na verdade, como dizia Hermógenes, essa tal semelhança seja uma coisa um tanto pegajosa, e que se nos torne necessário recorrer a este dispositivo grosseiro que é a convenção, para estabelecermos a correção dos nomes".
} 
todo nome chamado (kaleîn) é verdadeiro se houver sido previamente nomeado (ethémen). E toda nomeação é, pela força do ato, verdadeira. A relação kaleîn e ethémenn, doravante $K$ e $E$, não é bi-condicional em razão da possibilidade de nomeações individuais (privadas).

Assim, devemos alterar a TSF-C para a TSF-C2 da seguinte forma: seja $\mathrm{n}$ um nome, $\mathrm{x}$ uma coisa, dizemos: $x k n \Rightarrow x E n$ se é verdade que $\mathrm{x}$ é chamado de $\mathrm{n}$, então é verdade que $\mathrm{x}$ foi nomeado de $\mathrm{n}$, salvaguardando a possibilidade de $\mathrm{x}$ não ser chamado de $\mathrm{n}$ e ainda assim, $x k n \Rightarrow x E n$ ser verdadeira, pois $x k n$ pode ser falso e $x E n$ verdadeiro em casos de nomeação individual. ${ }^{48}$ Entretanto, há nesta reformulação uma encruzilhada. Para que $x E n$ seja verdadeiro, $\mathrm{n}$ deve ter sido construído sob um julgamento verdadeiro. Caso contrário, teríamos uma versão fraca de convencionalismo (chamada conservatism por Barney) identificada com o que é defendido por Protágoras (385d-386a). Obviamente, uma versão com que nem o próprio Hermógenes concorda (386a-b). Assim, pelo fato de nosso julgamento poder estar certo ou errado, i.e. basear-se na opinião ou no conhecimento, deve haver um critério (uma expertise) que faça a diferença na ação de nomear. E este critério não é, de modo algum, fruto de convenção. De fato, como aponta Barney (1997, p. 157 et seq.), o aspecto do convencionalismo aceito e apresentado por Hermógenes é normativo. Ou seja, pressupõe que os nomes já sejam todos corretos. O que sugere uma subordinação da TSF-C à TR-C e TS-C. Ora, isto não é desaprovado por Sócrates: exceto pela tese de que todos os nomes já sejam os corretos, o restante é comprovado pelo fato de se exigir justamente um conhecimento adequado que antecede o ato de nomear, se se pretende o uso correto do nome, este último sendo levado a cabo pelo dialético. Estes conhecimentos pressupostos no ato de nomear corretamente são os das Formas, da fonética e da semântica, portanto, os do domínio do nomoteta. O que nos permite reescrever a condicional acima para: seja $n$ um nome, $c$ uma coisa, Kcnxy significa " $c$ é chamado de $n$ por $x$ para $y$ ", $D x$ significa " $x$ é um dialético", $E c n z$ significa " $c$ é nomeado de $n$ por $z$ ", $T z$ significa " $z$ é um nomoteta", com a seguinte fórmula de conjunto:

$$
\text { (TSF-C2): } \exists x, y, z((K c n x y \wedge x \neq y \wedge D x) \rightarrow(E c n z \wedge T z))
$$

\footnotetext{
${ }^{48}$ De fato, a expressão inicial adequada para esta proposta é algo aproximadamente assim: seja n um nome, c uma coisa, $c K n x y$ significa: c é chamado de n por x e y, $c E n x$ significa: $\mathrm{c}$ é nomeado de $\mathrm{n}$ por $\mathrm{x}$, e dizemos então: $\exists x, y((c K n x y \wedge x \neq y) \rightarrow(c E n x \vee c E n y))$.
} 
Note que z pode ser y ou x. Mas x não pode ser y. Logo, é possível que $\mathrm{x}$ ou y seja um nomoteta (ou ambos sejam!), ou mesmo que nenhum deles o seja, contanto que tenha sido algum nomoteta a nomear o objeto c e que n seja usado por um dialético. Uma vez que ser um nomoteta exige, minimamente, o cumprimento de TR-C e TS-C, prova-se a subordinação referida acima. comparativo:

Agora, vejamos algumas considerações sobre o quadro

A. As teorias (TS-L) I e (TS-C) I são ambas livres de contexto (context-free), uma vez que dizem respeito à linguagem em geral. Portanto, assemelham-se.

B. Segundo (TS-L) II e (TS-C) II (a)-(b), e (TR-C) I, as teorias oferecem similarmente uma estrutura geral gramatical e funcional, principalmente se considerarmos a nota de rodapé de Kretzmann acerca do termo grego para nome (ónoma):

A palavra grega "ónoma" regularmente traduzida como "nome" foi usada no tempo de Platão e Aristóteles onde nós usaríamos "substantivo", "nome próprio", "nome comum", "descrição definida", "adjetivo", "particípio", e onde ocasionalmente também usaríamos "infinitivo" e "sujeito". ${ }^{49}$

C. Embora (TS-L) II (a)-(b) e (TS-C) II (a)-(b), e (TS-C) III sejam diferentes em princípio, já que o primeiro funciona com indexicais e o segundo com uma semântica composicional, ambos explicam como ocorre o significado (segundo regras sintáticas). Este procedimento marca o argumento, no caso do Crátilo, como o esboço de uma Teoria Semântica nos termos expostos acima.

D. Uma vez estabelecida uma Teoria semântica geral, não fica difícil deduzir uma Teoria Referencial: (TR-L) I assemelha-se

\footnotetext{
${ }^{49}$ Kretzmann, 1971, p. 126: "The Greek word ónoma regularly translated as 'name' was used at the time of Plato and Aristotle where we would use 'noun', 'proper name', 'common name', 'definite description', 'adjective', 'participle', and occasionally also where we would use 'infinitive' and 'subject'”.
} 
à concatenação de (TS-C) III e (TR-C) I, na medida em que a referência ocorre se há um nexo interno entre as expressões de uma linguagem particular e a estrutura (forma) da linguagem e essas expressões denotam inequivocamente as coisas. Assim, ambas executam a mesma função: ligar nomes às coisas (conceitos e objetos) e a valores de verdade. Especialmente, se considerarmos, tal como Kretzmann, a passagem 424e-425b do Crátilo.

E. Já as (TFS-L) e (TFS-C) se assemelham profundamente. Convenção e hábito (costume) são componentes necessários para estabelecer uma linguagem correta. Nisto, tanto Lewis quanto o Platão lido por Kretzmann concordam. A linguagem (sistema linguístico) é uma instituição social que é gestada no hábito de um ou mais indivíduos e do comum acordo entre eles (Lewis). Ela também se fundamenta neste conhecimento comum elaborado por sua prática (uso) (Platão). Ambas as formas de pensar permitem idioletos ${ }^{50}$ mas esta possibilidade não é condição suficiente para satisfazer uma teoria fundacional do significado, ela é apenas a sua condição inicial (1997, p. 148 et seq.), devendo ter a função de coordenação entre indivíduos (Lewis). No contexto do Crátilo, como aponta Barney, os nomes devem ser socialmente reconhecidos e mantidos, e isto, até certo ponto, define os nomes corretos (1997, p. 148 et seq.). O que vimos, da perspectiva de Kretzmann, pode ser pensado como a função de Instrução. Há, especialmente neste tópico, uma grande riqueza de aproximações e desdobramentos, mas deixaremos isto para futuros debates.

F. Ao passo que (TSF-L) e (TSF-C2) são aparentemente incompatíveis. Barney levanta alguns problemas na aproximação entre as teorias:

A hostilidade dos comentadores do Crátilo à própria ideia da nomeação privada é, ademais, um pouco difícil de entender.

\footnotetext{
${ }^{50}$ No caso de Lewis, esta afirmação é trivial. No caso de Platão, apresentada por Hermógenes (385d-386e), ela é normalmente apontada como uma teoria do significado anything goes (BARNEY, 1997, p. 146).
} 
Talvez valha a pena notar que mesmo a versão moderna do convencionalismo apresentada por David Lewis, na qual convenções são dependentes de expectativas interpessoais, não justificaria essa postura. Falando da linguagem de uma única pessoa, Lewis diz: "Tomando a definição literalmente, não haveria convenção. Mas, haveria algo bem similar... nós poderíamos pensar em uma situação na qual a convenção prevalece em uma população de diferentes fatias temporais de um mesmo homem" (op. cit. [Lewis, D. "Languages and Languages". In: Philosophical Papers. Oxford, 1983.] n. 10, p. 182). Nem o famoso argumento de Wittgenstein contra a possibilidade da linguagem privada fornece muita garantia para os ataques de Hermógenes, já que ele é (aparentemente) dirigido a uma linguagem que, diferentemente da nomeação privada convencionalista de Hermógenes, é em princípio inacessível mesmo a outros [Ludwig Wittgenstein, Philosophical investigations (Oxford, 1958)]. ${ }^{51}$

Há algo que podemos fazer para superá-las? Penso em três argumentos que distinguem o sentido da expressão "privado" (private). Há o sentido de relativamente privado e o sentido de absolutamente privado. Algo é relativamente privado se é contingentemente privado. Algo é absolutamente privado, se é necessariamente privado. Sejam por razões lógicas, epistemológicas ou ontológicas.

Argumento 1: Se Semântica e Fonética são, nos termos de Platão, indissociáveis, então não há como nomear com um nome absolutamente

\footnotetext{
${ }^{51}$ Wittgenstein, 1958, p. 155 (nota 20): "The hostility of the Cratylus commentators to the very idea of private naming is thus rather hard to understand. It is perhaps worth noting that even the modern version of conventionalism put forward by David Lewis, in which conventions are dependent on interpersonal expectations, would not warrant this stance. Speaking of a one-person language, Lewis says: 'Taking the definition literally, there would be no convention. But there would be something very similar.... We might think of the situation as one in which a convention prevails in the population of different time-slices of the same man' (op. cit. n. 10, p. 182). Nor does Wittgenstein's famous argument against the possibility of a private language provide much warrant for Hermogenes-bashing, since it is (apparently) aimed against a language which is, unlike a Hermogenean private naming convention, inaccessible even in principle to others" (trad. R. Heck).
} 
privado. Ao contrário, isso seria ininteligível como uma tentativa de nomear, até para o nomeador.

Argumento 2: O argumento da linguagem privada; o sobre a privacidade da dor; o do besouro na caixa de Wittgenstein [1994 (\$243293)], aos quais Barney se refere, compõem uma série de argumentos que formam uma reductio ad absurdum (BAKER, 1998, p. 325-356) contra a possibilidade da linguagem absolutamente privada, uma vez que a linguagem absolutamente privada não possuiria paralelo com nenhuma língua, sendo assim intraduzível. Logo, inexprimível, i.e. ininteligível para qualquer um que não fosse o criador da linguagem privada (de fato, nem mesmo ele seria capaz de compreender). No melhor dos cenários, é válido aceitar que um único sujeito faça uso de um idioma (idioleto) que ele mesmo criou, fazendo uso, assim, de uma linguagem contingentemente privada. E como isto não o impede de ensinar a outras pessoas seu código, o idioma não é necessariamente privado.

Argumento 3: Nomes não ocorrem isoladamente. O que somase ao argumento 1 e à noção já discutida em Lewis, de que linguagem é ação com vistas a um fim e o nome é apenas a etapa final da ação, que é bem mais complexa. Nomear com um nome totalmente privado demandaria uma ação privada de nomear, que, em última instância, por semelhança ao argumento 2, não deveria se parecer com uma ação pública de nomear (como um batismo), logo, ela correria o risco de ser uma ação incomunicável, portanto, absurda.

Deste modo, parece plausível aceitar duas coisas: 1. A possibilidade de produzir idioletos com apenas um falante, mas não um idioma absolutamente privado, ou seja, é perfeitamente aceitável a linguagem contingentemente privada. 2. Uma dimensão privada ${ }^{52}$ contendo a intenção de executar a ação de nomear. Mas todo o restante que decorre desta intenção é público. 3. Excluída a possibilidade da

\footnotetext{
${ }^{52} \mathrm{O}$ status dessa dimensão privada anterior a qualquer signo ou sistema linguístico, a intencionalidade, é atualmente do domínio da Filosofia da mente e, infelizmente, não cabe aqui discutirmos esta questão, muito embora seja promissora se associarmos a discussão contemporânea com a noção de intenção do falante discutida por Platão, os Estoicos e, especialmente, por Diodoro Cronos, que, a meu ver, em muito se parece com a noção de intencionalidade estritamente linguística de Wittgenstein nas Investigações filosóficas (WITTGENSTEIN, 1994/FREDE; INWOOD, 2005/SEDLEY, 1977).
} 
linguagem absolutamente privada, considera-se que a verdade de TSF- $\mathrm{C}_{2}$ está subordinada à TR-C e TS-C. Ao compararmos novamente com TSF-L, vemos que a semelhança é ainda maior que no caso $\mathrm{E}$, pois a TSF-C aceita facilmente inconsistências. Ou seja, TSF-C2 cumpre com todos os critérios levantados por TSF-L: é formal, envolve concordância entre um ou mais participantes, demanda um sistema linguístico de sinais e é direcionada à resolução de um problema.

Outra associação interessante é a das relações comunicador plateia e dialético - interlocutor. O modo como são conduzidas ambas as teorias (TSF-L e TSF- $\mathrm{C}_{2}$ ) demanda certa subordinação e confiança no método empregado por comunicador e dialético na condução do problema. Note que o papel do dialético para Platão não se limita à escolha dos nomes, mas inclui o fazer ver a existência (a entidade estável) das coisas, ou seja, sua Forma. Assim, podemos dizer que há uma dependência não só de uma liderança da atividade em ambos os casos, mas, além disso, uma confiança implícita no método executado pelo que toma a frente nesta atividade.

Por fim, cumpre esclarecermos a influência temporal ascendente e descendente entre o Crátilo de Platão e as teorias semânticas de Lewis citadas no início deste artigo. O caráter ascendente (a continuidade dos temas tratados no diálogo platônico por Lewis) é provado com dois argumentos: em primeiro lugar, todas as teorias de ambos os filósofos (ao menos, sob a ótica de Kretzmann, adicionada da crítica de Barney) postas em revista são compatíveis conforme vimos acima. Em segundo lugar, o todo destas teorias também é semelhante. Para Lewis, é condição necessária ter TR-L e TS-L satisfeitos para satisfazer TSF-L, uma vez que TSF-L é quem dá caráter vivo à linguagem, já dotada de semântica e sistema de referência; entretanto, na falta de TR e TS, TSF-L seria usada para construí-las. Para Platão não é tão diferente. A aceitação do convencionalismo ao final do diálogo mostra o reconhecimento da utilidade da linguagem em acompanhar o fluxo heraclitiano (que representa o nível do senso comum e da atividade diária), além de levantar a necessidade da existência de um nomoteta, mesmo não tendo logrado êxito na investigação dos últimos níveis etimológicos. Ademais, Platão também subordina TSF-C à TS-C e à TR-C como condição para um lógos verdadeiro. O que não significa, para ambos os filósofos, que a TS e a TR tenham a primazia, afinal o papel pragmático pressuposto à TSF em Lewis e o papel político da TSF em Platão são inegáveis e não elimináveis 
(BARNEY, 1997, p. 157 et seq.). Já o caráter descendente (a associação das teorias do significado de Lewis com as teorias contidas no Crátilo, deduzidas através da interpretação de Norman Kretzmann) é provado na formalização que acompanha a influência analítica na interpretação do comentador e dá um passo adiante, ao fornecermos uma revisão, com base em críticas consagradas, da TSF-C, o que contribui para o debate sobre a influência de Platão na Filosofia da linguagem contemporânea, além da tentativa de articulação da Filosofia da linguagem contida nas obras de ambos os filósofos, apesar dos milênios que os separam.

\section{Referências}

ACKRILL, J. J. Essays on Plato and Aristotle. Oxford: Oxford University Press, 1997.

ADEMOLLO, F. The Cratylus of Plato: a Commentary. Cambridge: Cambridge University Press, 2011.

ALCINO. The handbook of Platonism ("Didaskalikos”). Transl. John Dillon. New York: Oxford University Press, 2002.

ANGIONI, L. Introdução à teoria da predicação em Aristóteles. São Paulo: UNICAMP, 2006.

AUSTIN, J. L. Quando dizer é fazer: palavras e ação. Trad. Danilo Marcondes de Souza Filho. Porto Alegre: Artes Médicas, 1990.

BAKER, G. P. The private language argument. Language \& Communication, Amsterdam, v. 18, n. 4, p. 325-356, 1998.

BARNES, J. (Org.). Aristóteles. Trad. Ricardo Hermann Ploch Machado. São Paulo: Ideias \& Letras, 2009.

BARNES, J. (Org.). The Presocratic Philosophers. New York: Routledge, 1982.

BARNEY, R. Names and Nature in Plato's Cratylus. New York: Taylor \& Francis, 2001.

BARNEY, R. Plato on convencionalism. Phronesis, Leiden, v. 42, issue 2, p. 143-162, 1997.

BLANCHÊ, R. História da lógica: de Aristóteles a Bertrand Russel. Trad. António J. Pinto Ribeiro e Pedro Elói Duarte. Lisboa: Edições 70, 1996. 
BONAZZI, M.; HELMIG, C. Platonic Stoicism - Stoic Platonism: the dialogue between Platonism and Stoicism in Antiquity. Leuven: Leuven University Press, 2007.

CARNAP, R. Meaning and necessity. Chicago: University of Chicago Press, 1956.

CARNAP, R. Meaning and synonymy in natural languages. Philosophical Studies: an International Journal for Philosophy in the Analytic Tradition, Dordrecht, Springer, v. 6, n. 3, p. 33-47, 1955.

COFFA, A. The semantic tradition from Kant to Carnap. Cambridge: Cambridge University Press, 1991.

CORRIGAN, K.; TURNER, J. D. Plato's Parmenides and it's heritage: History and interpretation from Old Academy to later Platonism and Gnosticism. Atlanta: Society of Biblical Literature, 2010.

CORRIGAN, K.; TURNER, J. D. Platonisms: Ancient, Modern, and Postmodern: Ancient Mediterranean and medieval texts and contexts: studies in Platonism, Neoplatonism, and the Platonic tradition. Boston: Brill, 2007. v. 4.

DUMMET, M. Logical basis of Metaphysics. Harvard: Harvard University Press, 1991.

FILHO, D. M. S. The emergence of the notion of language. In: JANKOWSKY, K. R. (Org.). History of Linguistics, 1993: papers from the sixth International Conference on the History of the Language Science. Philadephia: John Benjamins, 1995. p. 37-46.

FREGE, G. Lógica e Filosofia da linguagem. Trad. Paulo Alcoforado. São Paulo: Edusp, 2009.

FREGE, G. O pensamento: uma investigação lógica. Trad. P. Alcoforado. Anais de Filosofia de São João del-Rei, São João del-Rei, n. 6, p. 283298, jul. 2009.

HAACK, S. Filosofia das lógicas. Trad. Cezar A. Mortari e Luiz H. de A. Dutra. São Paulo: Ed. Unesp, 1998.

HACKER, P. M. S. Analytic Philosophy: beyond the linguistic turn and back again. In: BEANEY, M. (Org.). The analytic turn. New York: Routledge, 2007. p. 125-141. 
HEDLEY, D.; HUTTON, S. (Org.). Platonism at the origins of modernity: studies on Platonism and early Modern Philosophy. Dordrecht: Springer, 2008.

KIRK, G. S.; RAVEN, J. E. The Presocratic Philosophers. New York: Cambridge University Press, 1957.

KNEALE, W.; KNEALE, M. The development of logic. Oxford: Clarendon Press, 1962.

KRETZMANN, N. Plato on the correctness of names. American Philosophical Quarterly, Champaign, n. 8, issue 2, p. 126-138, 1971.

LEWIS, D. Convention: a philosophical study. Oxford: Blackwell, 2002.

LEWIS, D. General Semantics. Synthese, Dordrecht, n. 22, p.18-67, 1970.

LONG, A. A. Stoic linguistics, Plato's "Cratylus" and Augustine's "Dialectica". In: FREDE, D.; INWOOD, B. Language and learning: philosophy of language in the Hellenistic age. Cambridge: Cambridge University Press, 2005. p. 36-55.

MARCONDES, D. Filosofia analítica. Rio de Janeiro: Jorge Zahar, 2004. MASLIN, K. T. Introdução à Filosofia da mente. Trad. Fernando José R. da Rocha. Porto Alegre: Artmed, 2009.

MONTENEGRO, M. A. P. Linguagem e conhecimento no "Crátilo" de Platão. Kriterion, Belo Horizonte, n. 116, p. 367-377, 2007.

MORTARI, C. A. Introdução à lógica. São Paulo: Ed. Unesp, 2001.

NOBILE, L. Words in the mirror: analysing the sensorimotor interface between phonetics and semantics in Italian. In: MICHELUCCI, P.; FISHER, O.; LJUNGBERG, C. (Org.). Semblance and signification. Philadelphia: John Benjamins Pub. Co., 2011. p. 101-131.

OLIVEIRA, M. A. Reviravolta linguístico-pragmática na Filosofia contemporânea. São Paulo: Loyola, 2006.

PENCO, Carlo. Introdução à Filosofia da linguagem. Rio de Janeiro: Vozes, 2004.

PlATÃO. A República. Trad. M. H. R. Pereira. Lisboa: Calouste Gulbenkian, 1990. 
PLATÃO. Crátilo. Trad. Maria J. Figueiredo. Lisboa: Instituto Piaget, 2001.

PLATÃO. Crátilo: ou sobre a correção dos nomes. Trad. Celso O. Vieira. São Paulo: Paulus, 2014.

PLATO. Plato in twelve volumes. Transl. Harold N. Fowler. Cambridge: Harvard University Press, 1921. v. 12.

RICHARDSON, M. True and false names in the "Cratylus". Phronesis, Leiden, v. 21, n. 2, p. 136-137, 1976.

ROFENA, C. The scales and the compass of Philosophy: Wittgenstein in the mirror of Plato. In: PERISSINOTTO, L.; CÁMARA, B. R. (Org.). Wittgenstein and Plato: connections, comparisons and contrasts. New York: Palgrave Macmillan, 2013. p. 72-99.

RORTY, R. The linguistic turn. Chicago: Chicago University Press, 1967. ROWETT, C. Plato, Wittgenstein and definition games. In: PERISSINOTTO, L.; CÁMARA, B. R. (Org.). Wittgenstein and Plato: connections, comparisons and contrasts. New York: Palgrave Macmillan, 2013. p. $196-220$.

RUNGGALDIER, E. Carnap's early conventionalism: an inquiry into the historical background of the Vienna Circle. Amsterdam: Rodopi, 1984.

SEDLEY, D. Diodorus Cronus and Hellenistic Philosophy. The Cambridge Classical Journal, Cambridge, v. 23, p. 74-120, 1977.

SEDLEY, D. Plato's Cratylus. Cambridge: Cambridge University Press, 2003.

SPELLMAN, L. Naming and knowing: the "Cratylus" on image. History of Philosophy Quarterly, Champaign, v. 10, n. 3, p. 197-210, july 1993.

TRABANT, J. Vico's new science of ancient signs: a study of Sematology. Transl. Sean Ward. New York: Routledge, 2004.

TUGEndHAT, E. Propedêutica lógico-semântica. Trad. Fernando Augusto da R. Rodrigues. Rio de Janeiro: Vozes, 2005.

WITTGENSTEIN, L. Investigações filosóficas. Trad. Marcos G. Montagnoli. Petrópolis: Vozes, 1994.

WITTGENSTEIN, L. Tractatus Logico-Philosophicus. Trad. Luiz Henrique Lopes dos Santos. São Paulo: Edusp, 2010 [1922]. 